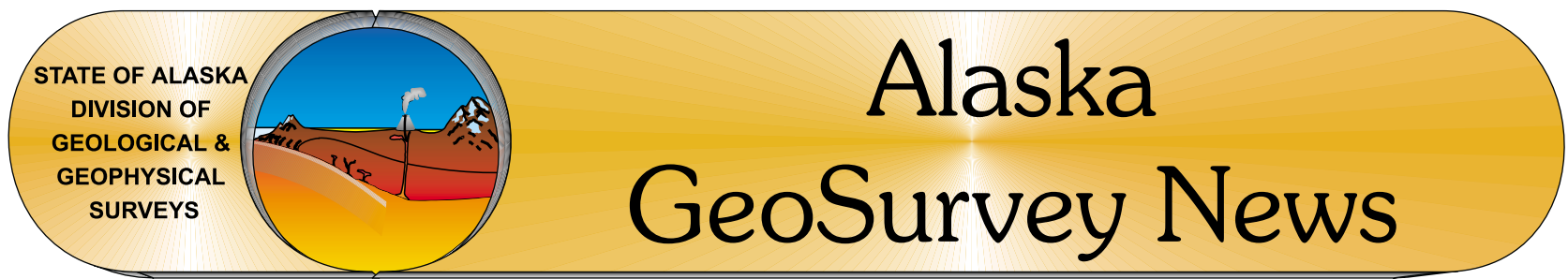

http://www.dggs.dnr.state.ak.us

Vol. 7, No. 2, September 2004

Note: The March 2004 NewSLETter Was INCORRECTLY LABELED AS Vol. 6, No. 1; IT SHOUld HAVE READ Vol. 7, No. 1.

\title{
APPLICATION OF REMOTE-SENSING IMAGERY AND 3-D VISUALIZATION IN THE COUNCIL MINING DISTRICT, SEWARD PENINSULA
}

DeAnne S.P. Stevens

\section{SUMmaRY}

The Alaska Division of Geological \& Geophysical Surveys (DGGS) is engaged in a NASA-funded project to help facilitate the economic viability of rural communities through increased placer mining opportunities. The project will apply remote-sensing imagery, multi-resolution digital elevation models (DEMs), and high-altitude color-infrared photography in conjunction with knowledge of geomorphology, surficial deposits, and bedrock geology, to evaluate the placer gold potential of part of the Council placer mining district on the Seward Peninsula, northwestern Alaska. Additionally, as part of our commitment to the rural people of the Seward Peninsula, we have presented a series of educational workshops in Nome to teach interested members of the communities impacted by this research how to understand, interpret, and apply the map and GIS products that will be generated by the study.

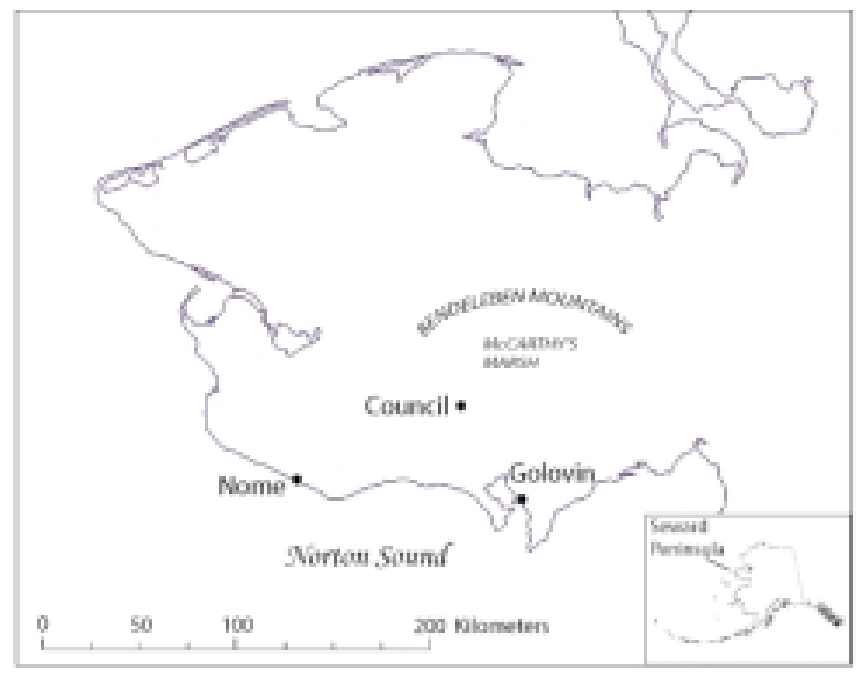

Map of Seward Peninsula.

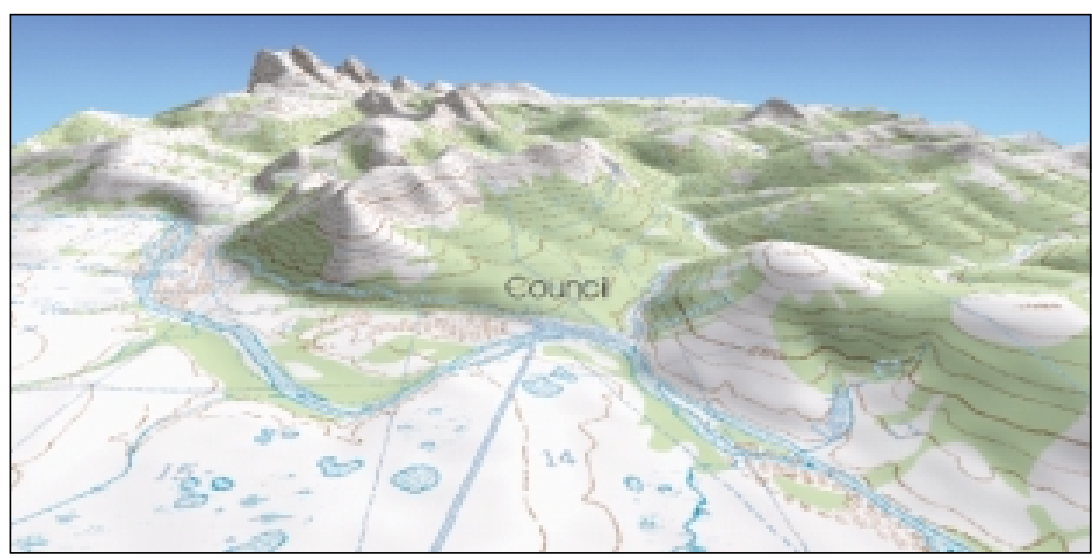

Virtual three-dimensional landscape model of the Council area generated by draping digital topographic map over inSAR-derived DEM with $4 X$ vertical exaggeration. View is to north. Landscape models can help users learn to interpret topographic maps and visualize the geography of an area.

\section{BACKGROUND}

In March 2000, regional and village Native Alaskan leaders met in Kotzebue, northwestern Alaska, to discuss avenues for preserving the indigenous cultures of Alaska and increasing the quality of life for their communities. The Arctic Economic Development Summit determined that new economic development in rural Alaska results in higher employment; greater access to health care, water, sewer and transportation; and a tax base or payments that can support schools and needed social services. Further, they asserted that development projects ultimately provide greater selfsufficiency and determination over the future for the Native communities. Historically, small-scale placer gold mines have been readily available as a means of generating income in rural areas. Between 1992 and 2001, however, 780 of a total 1,251 placer mining jobs had been lost statewide. Most of these jobs were located in rural Alaska and provided well paying seasonal employment to local residents. Part of the reason for the decline is that most placer districts are perceived as mined out. Preliminary examination of aerial photographs, however, suggested that untapped placer re- 


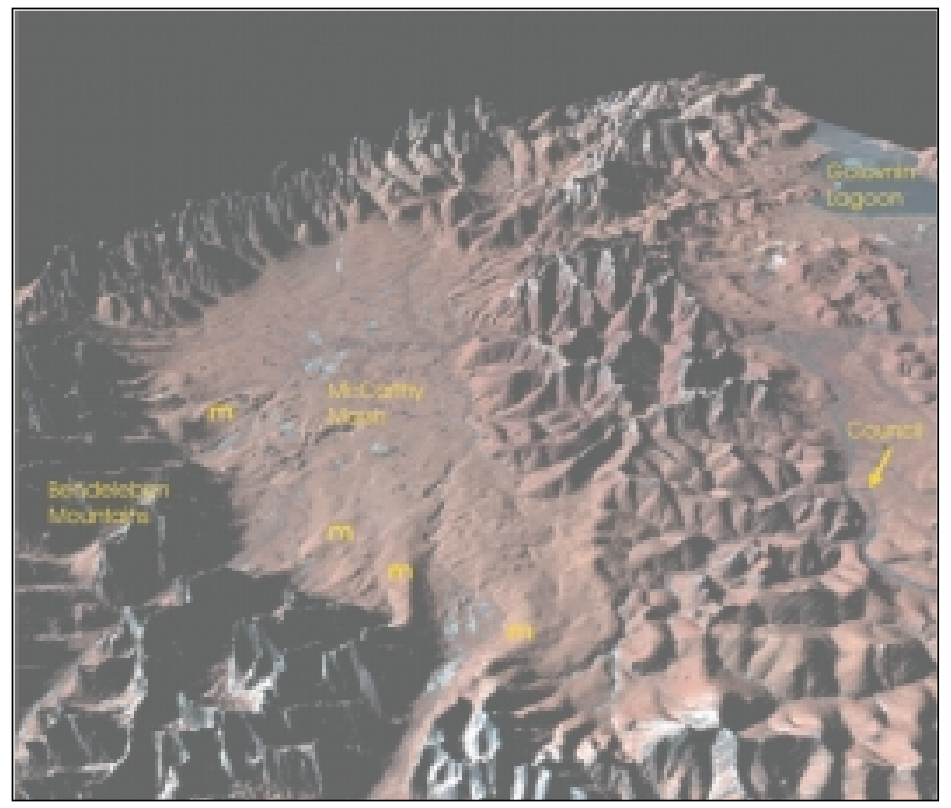

Virtual three-dimensional landscape model of the Council area generated by draping Landsat-7 ETM+ imagery (bands 23-4 displayed as blue-green-red) over NED-derived DEM with $8 X$ vertical exaggeration. The extreme vertical exaggeration and low sun angle combine to enhance the surface expression of the moraines fronting the Bendeleben Mountains (indicated by “" $m$ "). View is to southeast.

serves might still be present. Alaska's Senator Ted Stevens, working with NASA, obtained congressional funding to address projects in Alaska that might benefit from remote-sensing technology. Remote sensing involves analyzing and extracting useful information from images taken from aircraft and spacecraft, including aerial photography and satellite imagery. The DGGS project discussed here is one of eight statewide selected for funding.

\section{Project Strategy}

Our strategy to identify potential untapped placer resources is based on what we know about placer deposits. Placers are generally water-laid deposits, usually gravel, that are enriched in valuable minerals (gold, platinum, and diamonds are the most familiar commodities), and are formed when the original lode deposit (rock) is gradually broken apart by erosion (physical and chemical processes) and the resulting material is transported into streams where water has a tendency to remove less-dense components and leave denser material behind. Over time, the stream bottom may develop sufficiently high concentrations of the dense commodities to be economi- cally valuable. It is clear, then, that geomorphology is key to locating placers: Landforms are geologic indicators of past stream activity and thus of placer potential. The targets of our search in the Council area include stream terraces, buried and abandoned paleochannels, and some classes of glacial deposits, all within the context of a geologic framework where they occur in association with known placers and/or have ancestral headwaters in known gold-bearing rocks. Such landforms and their age relationships are often subtle and require accurate topographic control to either recognize or correctly spatially relate to one another. Because of this, DGGS is particularly interested in developing the in-house capability to perform image draping and generate three-dimensional block diagrams that promise to be especially useful in visualizing the data in a topographic context that permits discernment of subtle landforms.

The project is being implemented in two phases: Phase I, regional evaluation using lower-resolution data; and Phase II, detailed evaluation using higher-resolution data. Additionally, high-altitude color-infrared aerial photographs are being used to cross-check satellite imagery classifications, produce tradi-

Virtual three-dimensional landscape model of the Council area generated by draping QuickBird multispectral imagery (bands 1-2-3 displayed as blue-green-red) over inSAR-derived DEM with $3 X$ vertical exaggeration. This satellite image was collected in September 2003, and the bright colors on the hills are fall vegetation. Bedrock is principally marble, which appears white in this image, as does the Nome-Council road seen in the foreground. View is to north.

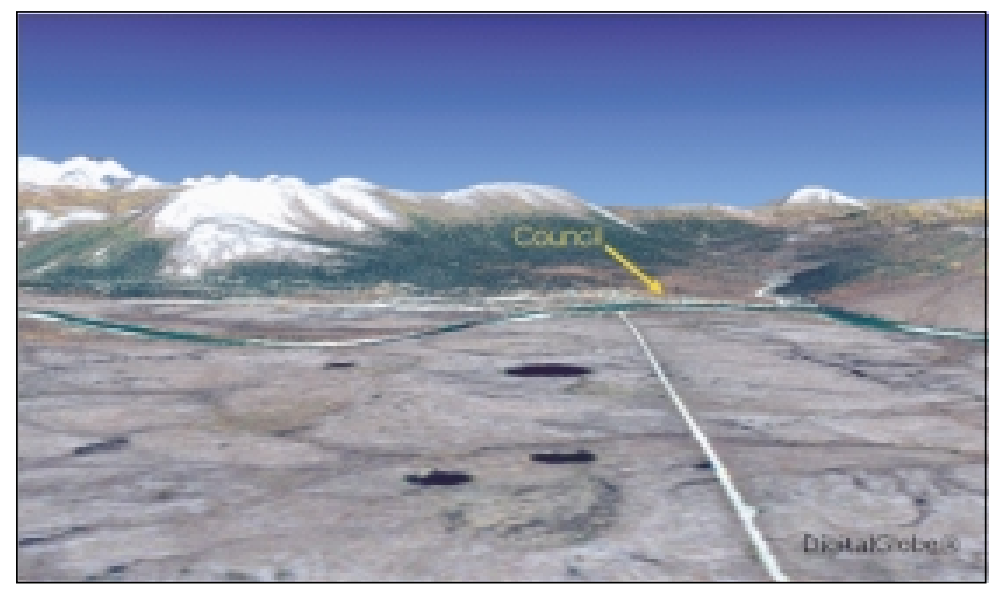


tional photointerpreted geologic maps, and to generate geographically corrected orthophoto base maps that will be useful for many other applications in the Council area.

\section{Results}

Phase I of the project involves regional landform analysis using Landsat-7 ETM+ imagery and a digital elevation model (DEM) from the USGS National Elevation Database (NED). DEMs are digital datasets in which each geospatially located cell (analogous to a pixel) is assigned a value corresponding to its elevation. Landsat-7 ETM+ imagery has a spatial resolution of $30 \mathrm{~m}$ for its six-band multispectral data, and the NED DEM has a 60-m cell resolution in the study area. In addition to virtual three-dimensional image drapes, we are evaluating the utility of the imagery in distinguishing key geomorphic features by applying remote-sensing analysis techniques that include edge detection, principal component analysis, and supervised and unsupervised classification. While we are able to distinguish many key geomorphic features at this level, critical distinctions cannot yet be made regarding some important groups of glacial deposits. Distinguishing between different ages of glacial deposits should theoretically be possible because the different-aged surfaces should be characterized by different vegetation and surface expression, especially roughness. Older surfaces would have experienced more post-depositional smoothing due to periglacial processes such as solifluction. However, the scale of the Phase I data is proving too coarse to distinguish anything but the largest features. Nevertheless, combining spectral, geologic, and topographic data to generate virtual 3-D landscape models at this scale shows great potential as a powerful analytical tool on a regional level, as well as being an instantly intuitive means of portraying the data relationships to the general public.

QuickBird imagery, with a resolution of $2.4 \mathrm{~m}$ for its four-band multispectral data, was selected for Phase II detailed analysis. The Phase II evaluation uses DEMs with 30-m cell resolution that were generated by the Alaska SAR Facility (ASF) from ERSderived Tandem Mission radar data processed using interferometric SAR (inSAR) methods. As in Phase $\mathrm{I}$, we are generating virtual three-dimensional image drapes as well as evaluating the imagery using edge detection, principal component analysis, and supervised and unsupervised classification. Possible additional future investigations may include applying roughness algorithms and slope analysis using the inSAR DEMs in an attempt to differentiate between degrees of smoothing on surfaces of different ages. Again, the most useful analytical tools for the project to date are the virtual 3-D image models,

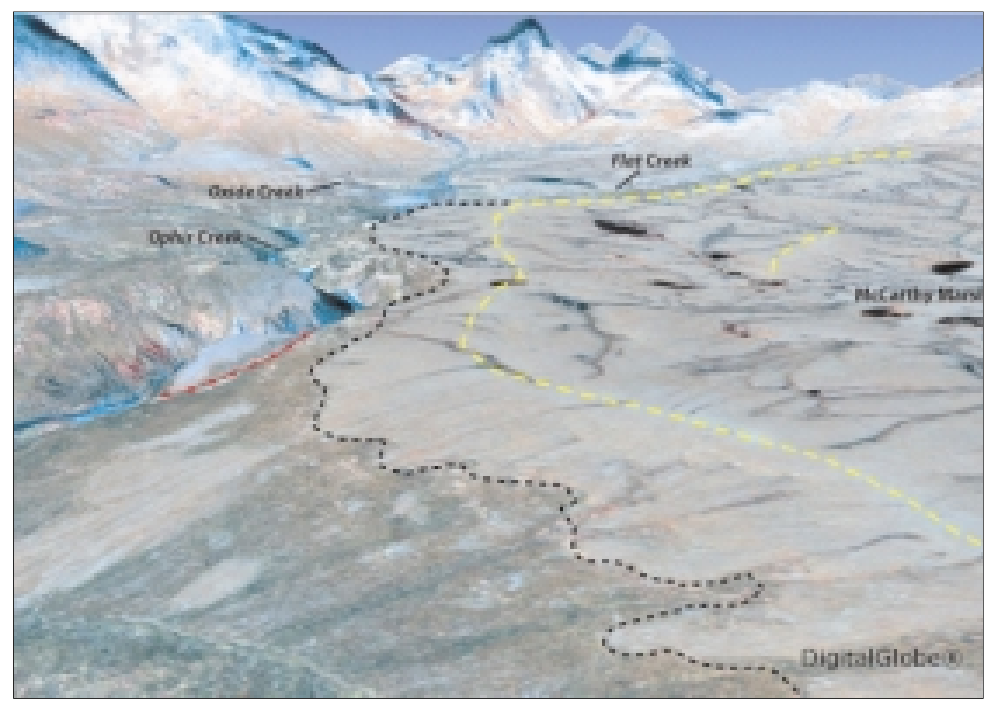

Virtual three-dimensional landscape model of upper Ophir Creek generated by draping QuickBird multispectral imagery (bands 1-2-4 displayed as blue-green-red) over inSAR-derived DEM with $3 X$ vertical exaggeration. Dashed yellow lines are moraine crests of the pre-Wisconsin Sinuk Glaciation, black dashed line is limit of preserved Sinuk-age moraine deposits, and red arrows show abandoned paleochannel incised by Ophir Creek. View is to northwest. In pre-glacial times upper Ophir Creek, Oxide Creek, and Flat Creek probably drained to the east across what is now McCarthy Marsh. Advancing glaciers pushed the streams southwestward and eventually completely diverted them to their modern southern flow.

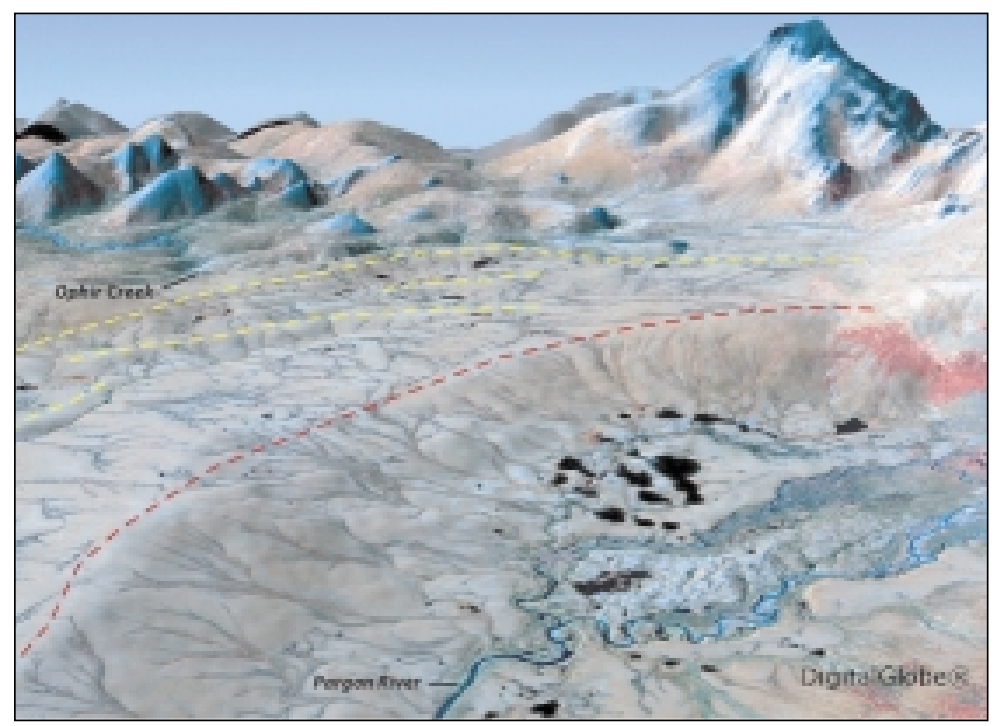

Virtual three-dimensional landscape model of Pargon River - upper Ophir Creek area generated by draping QuickBird multispectral imagery (bands 1-2-4 displayed as blue-green-red) over inSAR-derived DEM with $3 X$ vertical exaggeration. Dashed yellow lines are moraine crests of the pre-Wisconsin Sinuk Glaciation, dashed red line is moraine crest of pre-Wisconsin Nome River Glaciation. View is to west-southwest. Glaciers in the Bendeleben Mountains carved Pargon River valley and advanced across McCarthy Marsh, filling the basin with glacial sediments and changing the courses of streams like Ophir Creek. 


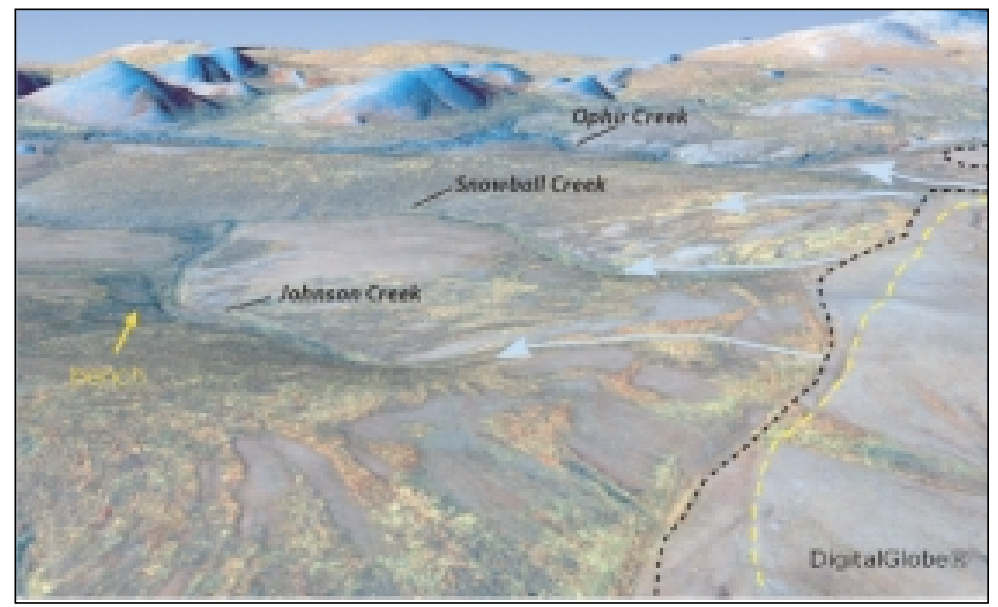

Virtual three-dimensional landscape model of upper Ophir Creek generated by draping QuickBird multispectral imagery (bands 1-2-4 displayed as blue-green-red) over inSAR-derived DEM with $3 X$ vertical exaggeration. This satellite image was collected in September 2003, and the bright colors on the hills are fall vegetation. Bedrock is principally marble and schist, which appear blue in this image. Dashed yellow line is moraine crest of the preWisconsin Sinuk Glaciation, black dashed line is limit of preserved Sinuk-age moraine deposits, and blue arrows show proglacial meltwater drainages feeding into the heads of Johnson and Snowball creeks. View is to west. Glaciers originating in the Bendeleben Mountains advanced across McCarthy Marsh and overtopped ridges at the heads of modern Johnson and Snowball creeks. Large volumes of proglacial meltwater flowed into these valleys, draining southward and carving subdued, elevated bedrock benches like the one marked.

which allow us to analyze the landscape using a powerful combination of manipulation of multi-band spectral data over threedimensional topography that can be enhanced by user-controlled vertical exaggeration, sun angles, and viewing geometry. The geospatial relationships between landscape and geology are apparent to professional and layperson alike.

It is clear that the new remote-sensing technologies will be extremely useful in future geologic investigations, but they are best used in conjunction with traditional air photo based methods, not instead of them. Ground truthing is a critical requirement, as it is in all image-based (e.g., air photo) analyses, and the new technologies require high-end computers and expensive software in order to be utilized effectively. DGGS remains committed to using these tools to better serve the needs of communities throughout Alaska. Upon completion of this project, we will employ remote-sensing technology in engineering-geology assessments of flood-plain hazards, transportation corridor analysis, re-assessment of mining potential in historical placer districts throughout the state, and in conducting construction-material inventories. Many additional applications will likely become apparent over time.

\section{Products}

Products from this study will consist of detailed geologic maps of unconsolidated Quaternary sedimentary deposits in the Council area and appropriate cross-sections and three-dimensional landform models. The maps and models will display the spatial relationships between deposits that are fundamental to understanding the Quaternary geologic history of the mining district and identifying the most probable location and extent of currently undiscovered placer gold-bearing deposits. All map products will be produced in conformance with NGDC standards, will be in ESRI ArcGIS format, and available for viewing and download on the DGGS Web site. Anticipated release date is spring 2005. In addition to the educational workshops that have already been held in Nome in 2002 and 2003, a final workshop is scheduled for summer 2005 that will focus on interpreting and using the completed map and GIS products generated for the Council mining district.

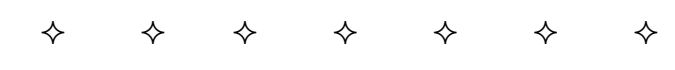

\begin{tabular}{|c|}
\hline Please send address corrections to: \\
Newsletter, Alaska Division of Geological \& Geophysical Surveys \\
794 University Ave., Suite 200, Fairbanks, AK 99709-3645 \\
(907) 451-5020 $\quad(907) 451-5050$ fax \\
email: dggsnews@dnr.state.ak.us \\
http://wwwdggs.dnr.state.ak.us
\end{tabular}

\section{Visit our web page at http://wwwdggs.dnr.state.ak.us}

Page 4 • September 2004 
This issue of GeoSurvey News highlights the use of modern remote-sensing technology as part of a multi-disciplinary approach to addressing practical problems in landform analysis and geologic mapping. We are excited about the potential outcome of this project for helping to identify possible untapped placer-mineral resources on Seward Peninsula and look forward to applying the technology to many other practical geologic-resource and hazards problems around Alaska.

When you call or visit our office you will have an opportunity to meet Sean Willison, who has taken the position of Natural Resource Technician, replacing Dawn Roberts at the front desk. After three years of productive service to DGGS managing the geology library and cheerfully responding to public inquiries, Dawn was accepted to a master's degree program in museology at the University of Washington. We congratulate Dawn and wish her the best in her graduate studies. Sean comes to us with an academic background and work experience in natural resource management, now completing course work for a bachelor's degree in NRM at UAF. We welcome him into his new position at DGGS.
Last but not least, Gail Davidson retired at the end of August after 25 years of service with DGGS. For the past several years, in her position as chief of the Geologic Communications section, Gail oversaw the entire range of internal and external communications processes in the division, including map \& report production, public information, Web site development, geographic information system (GIS), microcomputers, and network services. We congratulate Gail for her many lasting contributions to DGGS and wish her the very best in her new endeavors. Long-time DGGS employee Paula Davis is now serving as acting chief of GeoComm.

Sincerely,

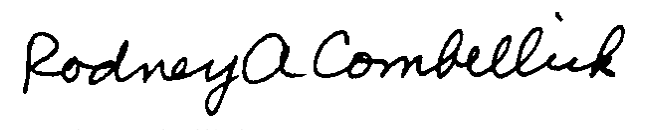

Rod Combellick,

Acting Director

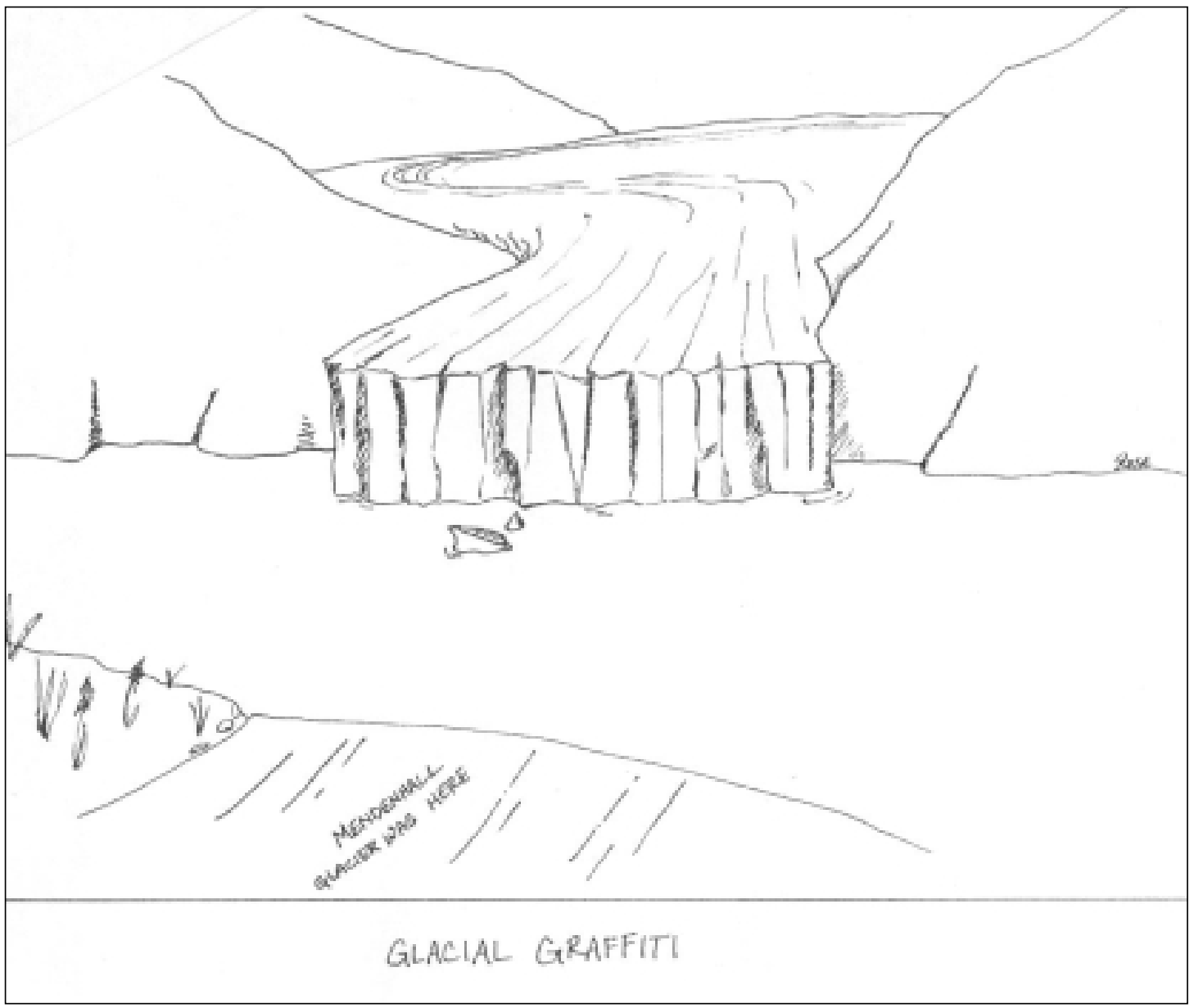




\section{GEOPHYSICAL MAPS \& REPORTS}

GPR 2004_1. Selected plot files of the airborne geophysical survey data of the Fairbanks and Richardson areas, interior Alaska. 1 CD-ROM. Contains the $\mathbf{1 2}$ maps listed below as GPR2004_1_xy in both HPGL/2 format and postscript printer format. Software is needed with ability to plot HPGL2 files for an HP Design Jet 5000 series plotter or postscript files designed for an HP Design Jet Designjet 2500 using Postscript 3 printer driver v5.0. The postscript files should plot on all Hewlett Packard plotters that can interpret Postscript 3 files. $\$ 10$.

GPR 2004_1_1a. Total magnetic field of the Fairbanks mining district, interior Alaska, 2 sheets, scale 1:63,360. Topography included. Full-color plot from electronic file, 600 dpi. \$26.

GPR 2004_1_1b. Total magnetic field of the Fairbanks mining district, interior Alaska, 2 sheets, scale 1:63,360. Magnetic contours and section lines included. Full-color plot from electronic file, 600 dpi. $\$ 26$.

GPR 2004_1_2a. $7200 \mathrm{~Hz}$ coplanar resistivity of the Fairbanks mining district, interior Alaska, 2 sheets, scale 1:63,360. Topography included. Full-color plot from electronic file, 600 dpi. $\$ 26$.

GPR 2004_1_2b. $7200 \mathrm{~Hz}$ coplanar resistivity of the Fairbanks mining district, interior Alaska, 2 sheets, scale 1:63,360. Resistivity contours and section lines included. Full-color plot from electronic file, 600 dpi. \$26.

GPR 2004_1_3a. 900 Hz coplanar resistivity of the Fairbanks mining district, interior Alaska, 2 sheets, scale 1:63,360. Topography included. Full-color plot from electronic file, 600 dpi. $\$ 26$.

GPR 2004_1_3b. $900 \mathrm{~Hz}$ coplanar resistivity of the Fairbanks mining district, interior Alaska, 2 sheets, scale 1:63,360. Resistivity contours and section lines included. Full-color plot from electronic file, 600 dpi. \$26.

GPR 2004_1_4a. Total magnetic field of the Richardson mining district, interior Alaska, 1 sheet, scale 1:63,360. Topography included. Full-color plot from electronic file, 600 dpi. \$13.

GPR 2004_1_4b. Total magnetic field of the Richardson mining district, interior Alaska, 1 sheet, scale 1:63,360. Magnetic contours and section lines included. Full-color plot from electronic file, 600 dpi. $\$ 13$.

GPR 2004_1_5a. $7200 \mathrm{~Hz}$ coplanar resistivity of the Richardson mining district, interior Alaska, 1 sheet, scale 1:63,360. Topography included. Full-color plot from electronic file, $600 \mathrm{dpi}$. $\$ 13$.

GPR 2004_1_5b. $7200 \mathrm{~Hz}$ coplanar resistivity of the Richardson mining district, interior Alaska, 1 sheet, scale 1:63,360. Resistivity contours and section lines included. Full-color plot from electronic file, 600 dpi. $\$ 13$.

GPR 2004_1_6a. $900 \mathrm{~Hz}$ coplanar resistivity of the Richardson mining district, interior Alaska, 1 sheet, scale 1:63,360. Topography included. Full-color plot from electronic file, $600 \mathrm{dpi}$. $\$ 13$.

GPR 2004_1_6b. $900 \mathrm{~Hz}$ coplanar resistivity of the Richardson mining district, interior Alaska, 1 sheet, scale 1:63,360. Resistivity contours and section lines included. Full-color plot from electronic file, 600 dpi. \$13.

GPR 2004_2. Line, gridded, and vector data of airborne geophysical survey data for the Fairbanks and Richardson mining districts, interior Alaska. 1 CD-ROM set. Line data in ASCII format; gridded data in Geosoft format; vector files in Autocad 13 dxf files. $\$ 20$.
GPR 2004_3. Line, gridded, and vector data, and selected plot files of the airborne geophysical survey data of the Valdez Creek mining district, central Alaska, by L.E. Burns, Fugro Airborne Surveys Corp., and Stevens Exploration Management Corp. 1 CD-ROM. Line data in ASCII format; gridded data in Geosoft format and ER Mapper; vector files in Autocad 13 dxf files. 12 maps listed below as GPR2004_3_xy are included as plot files for in both HPGL/2 format and postscript printer format. Software is needed with ability to plot HPGL2 files for an HP Design Jet 5000/5500 series plotter or postscript files designed for an HP Design Jet Designjet 5000/5500 using Postscript 3 printer driver v5.0. The postscript files should plot on all Hewlett Packard plotters that can interpret Postscript 3 files. Supercedes PDF 94-15 and PDF 94-35. \$10.

GPR 2004_3_1a. Total magnetic field of the Valdez Creek mining district, central Alaska, by L.E. Burns, Fugro Airborne Surveys Corp., and Stevens Exploration Management Corp., 2004, 1 sheet, scale 1:63,360. Full-color map; topography included. Supercedes RI 94-18; see also GPR 2004_3_lb. \$13.

GPR 2004_3_1b. Total magnetic field of the Valdez Creek mining district, central Alaska, by L.E. Burns, Fugro Airborne Surveys Corp., and Stevens Exploration Management Corp., 2004, 1 sheet, scale 1:63,360. Full-color map; magnetic contours and section lines included. Supercedes RI 94-18; see also GPR 2004_3_1a. \$13.

GPR 2004_3_2a. $7200 \mathrm{~Hz}$ coplanar resistivity of the Valdez Creek mining district, central Alaska, by L.E. Burns, Fugro Airborne Surveys Corp., and Stevens Exploration Management Corp., 2004, 1 sheet, scale 1:63,360. Full-color map; topography included. Supercedes RI 94-20; see also GPR 2004_3_2b. \$13.

GPR 2004_3_2b. $7200 \mathrm{~Hz}$ coplanar resistivity of Valdez Creek mining district, central Alaska, by L.E. Burns, Fugro Airborne Surveys Corp., and Stevens Exploration Management Corp., 2004, 1 sheet, scale 1:63,360. Full-color map; resistivity contours and section lines included. Supercedes RI 94-20; see also GPR 2004_3_2a. \$13.

GPR 2004_3_3a. $900 \mathrm{~Hz}$ coplanar resistivity of the Valdez Creek mining district, central Alaska, by L.E. Burns, Fugro Airborne Surveys Corp., and Stevens Exploration Management Corp., 2004, 1 sheet, scale 1:63,360. Full-color map; topography included. Supercedes RI 94-21; see also GPR 2004_3_2b. \$13.

GPR 2004_3_3b. $900 \mathrm{~Hz}$ coplanar resistivity of the Valdez Creek mining district, central Alaska, by L.E. Burns, Fugro Airborne Surveys Corp., and Stevens Exploration Management Corp., 2004, 1 sheet, scale 1:63,360. Full-color map; resistivity contours and section lines included. Supercedes RI 94-21; see also GPR 2004_3_2a. \$13.

GPR 2004_4. Line, gridded, and vector data, and selected plot files from the aeromagnetic survey of the Nyac mining district, central Alaska, by L.E. Burns, Fugro Airborne Surveys Corp., and Stevens Exploration Management Corp. 1 CD-ROM. Line data in ASCII format; gridded data in Geosoft format; vector files in Autocad $13 \mathrm{dxf}$ files. 2 maps listed below as GPR2004_4_1a and 1b are included as plot files for in both HPGL/2 format and postscript printer format. Software is needed with ability to plot HPGL2 files for an HP Design Jet 5000/5500 series plotter or postscript files designed for an HP Design Jet Designjet 5000/5500 using Postscript 3 printer driver v5.0. The postscript files should plot on all Hewlett Packard plotters that can interpret Postscript 3 files. Supercedes PDF 94-15 and PDF 94-34. \$10. 
GPR 2004_4_1a. Total magnetic field of the Nyac mining district, central Alaska, by L.E. Burns, Fugro Airborne Surveys Corp., and Stevens Exploration Management Corp., 2004, 1 sheet, scale 1:63,360. Full color map; topography included. See also GPR 2004_4_1b. $\$ 13$.

GPR 2004_4_1b. Total magnetic field of the Nyac mining district, central Alaska, by L.E. Burns, Fugro Airborne Surveys Corp., and Stevens Exploration Management Corp., 2004, 1 sheet, scale 1:63,360. Full color map; magnetic contours and section lines included. See also GPR 2004_4_la. \$13.

GPR 2004_5. Line, gridded, and vector data, and selected plot files of the airborne geophysical survey data of the Circle mining district, central Alaska, by L.E. Burns, Fugro Airborne Surveys Corp., and Stevens Exploration Management Corp., 2004, 1 CDROM. Contractor's report, previously released as PDF 94-36, is also included. Line data in ASCII format; gridded data in Geosoft and ER Mapper format; vector files in Autocad $13 \mathrm{dxf}$ files. 6 maps listed below as GPR 2004_5_1a through 3b are included as plot files for in both HPGL/2 format and postscript printer format. Software is needed with ability to plot HPGL2 files for an HP Design Jet 5000/5500 series plotter or postscript files designed for an HP Design Jet Designjet 5000/5500 using Postscript 3 printer driver v5.0. The postscript files should plot on all Hewlett Packard plotters that can interpret Postscript 3 files. Supercedes PDF 94-15 and PDF 94-33. \$10.

GPR 2004_5_1a. Total magnetic field of the Circle mining district, interior Alaska, by L.E. Burns, Fugro Airborne Surveys Corp., and Stevens Exploration Management Corp., 2004, 1 sheet, scale 1:63,360. Full color map; topography included. Supercedes RI 94-14; see also GPR 2004_5_1b \$13.

GPR 2004_5_1b. Total magnetic field of the Circle mining district, interior Alaska, by L.E. Burns, Fugro Airborne Surveys Corp., and Stevens Exploration Management Corp., 2004, 1 sheet, scale 1:63,360. Full color map; magnetic contours and section lines included. Supercedes RI 94-14; see also GPR 2004_5_1a. \$13.

GPR 2004_5_1c. Color shadow total magnetic field of the Circle mining district, interior Alaska, by L.E. Burns, Fugro Airborne Surveys Corp., and Stevens Exploration Management Corp., 2004, 1 sheet, scale 1:63,360. Full color map; section lines included. Supercedes RI 94-15. \$13.

GPR 2004_5_2a. $7200 \mathrm{~Hz}$ coplanar apparent resistivity of the Circle mining district, interior Alaska, by L.E. Burns, Fugro Airborne Surveys Corp., and Stevens Exploration Management Corp., 2004, 1 sheet, scale 1:63,360. Full color map; topography included. Supercedes RI 94-16; see also GPR 2004_5_2b. $\$ 13$.

GPR 2004_5_2b. $7200 \mathrm{~Hz}$ coplanar apparent resistivity of the Circle mining district, interior Alaska, by L.E. Burns, Fugro Airborne Surveys Corp., and Stevens Exploration Management

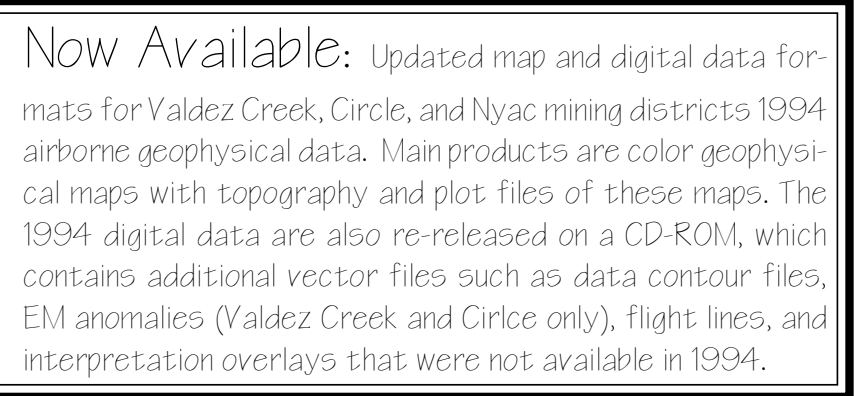

Corp., 2004, 1 sheet, scale 1:63,360. Full color map; resistivity contours and section lines included. Supercedes RI 94-16; see also GPR 2004_5_2a. \$13.

GPR 2004_5_3a.900 Hz coplanar apparent resistivity of the Circle mining district, interior Alaska, by L.E. Burns, Fugro Airborne Surveys Corp., and Stevens Exploration Management Corp., 2004, 1 sheet, scale 1:63,360. Full color map; topography included. Supercedes RI 94-17; see also GPR 2004_5_3b. \$13.

GPR 2004_5_3b. $900 \mathrm{~Hz}$ coplanar apparent resistivity of the Circle mining district, interior Alaska, by L.E. Burns, Fugro Airborne Surveys Corp., and Stevens Exploration Management Corp., 2004, 1 sheet, scale 1:63,360. Full color map; Resistivity contours and section lines included. Supercedes RI 94-17; see also GPR 2004_5_3a. \$13.

\section{MISCELLANEOUS PUBLICATIONS}

MP 45-122. Survey of geology, geologic materials, and geologic hazards in proposed access corridors in the (see list below) Quadrangle, Alaska

MP 45. Ambler River, 5 sheets. $\$ 65$.

MP 46. Anchorage, 5 sheets. $\$ 65$.

MP 47. Baird Mountains, 4 sheets. \$53.

MP 48. Barrow, 5 sheets. $\$ 65$.

MP 49. Barter Island, 5 sheets. $\$ 65$.

MP 50. Beechey Point, 5 sheets. $\$ 65$.

MP 51. Bendeleben Mountains, 5 sheets. $\$ 65$.

MP 52. Bering Glacier, 5 sheets. $\$ 65$.

MP 53. Bethel, 5 sheets. $\$ 65$.

MP 54. Bettles, 5 sheets. $\$ 65$.

MP 55. Black River, 5 sheets. $\$ 65$.

MP 56. Bradfield Canal, 5 sheets. $\$ 65$.

MP 57. Candle, 5 sheets. $\$ 65$.

MP 58. Chandalar, 5 sheets. $\$ 65$

MP 59. Chandler Lake, 5 sheets. $\$ 65$.

MP 60. Charley River, 5 sheets. $\$ 65$.

MP 61. Chignik Point, 5 sheets. $\$ 65$.

MP 62. Circle, 5 sheets. $\$ 65$.

MP 63. Cold Bay, 5 sheets. $\$ 65$.

MP 64. Cordova, 5 sheets. $\$ 65$.

MP 65. DeLong Mountains, 5 sheets. $\$ 65$.

MP 66. Demarcation Point, 5 sheets. $\$ 65$.

MP 67. Dillingham, 4 sheets. \$52.

MP 68. Eagle, 5 sheets. $\$ 65$.

MP 69. Fairbanks, 5 sheets. $\$ 65$.

MP 70. Flaxman Island. \$65.

MP 71. Harrison Bay, 5 sheets. \$65.

MP 72. Healy, 5 sheets. \$65.

MP 73. Holy Cross, 5 sheets. \$65.

MP 74. Howard Pass, 5 sheets. \$65.

MP 75. Hughes, 5 sheets. $\$ 65$.

MP 76. Iditarod, 4 sheets. $\$ 52$.

MP 77. Ikpikpuk, 5 sheets. $\$ 65$.

MP 78. Iliamna, 5 sheets. $\$ 65$.

MP 79. Juneau, 4 sheets. $\$ 52$.

MP 80. Kantishna River, 5 sheets. \$65.

MP 81. Karluk, 5 sheets. \$65.

MP 82. Kateel River, 5 sheets. \$65.

MP 83. Killik River, 5 sheets. $\$ 65$.

MP 84. Lake Clark, 4 sheets. \$52.

MP 85. Lime Hills, 4 sheets. \$52.

MP 86. Livengood, 5 sheets. $\$ 65$

MP 87. Lookout Ridge, 5 sheets. $\$ 65$

MP 88. McGrath, 5 sheets. $\$ 65$. 
MP 89. Meade River, 5 sheets. $\$ 65$.

MP 90. Medfra, 5 sheets. $\$ 65$.

MP 91. Melozitna, 5 sheets. $\$ 65$.

MP 92. Misheguk Mountain, 5 sheets. \$65.

MP 93. Mount Katmai, 5 sheets. $\$ 65$.

MP 94. Mount McKinley, 5 sheets. \$65.

MP 95. Mount Michelson, 5 sheets. $\$ 65$.

MP 96. Naknek, 4 sheets. \$52.

MP 97. Noatak, 4 sheets. \$52.

MP 98. Norton Bay, 5 sheets. $\$ 65$.

MP 99. Nulato, 5 sheets. $\$ 65$.

MP 100. Ophir, 5 sheets. $\$ 65$.

MP 101. Petersburg, 5 sheets. $\$ 65$.

MP 102. Philip Smith Mountains, 5 sheets. $\$ 65$.

MP 103. Port Moller, 5 sheets. $\$ 65$.

MP 104. Ruby, 4 sheets. \$52.

MP 105. Russian Mission, 5 sheets. $\$ 65$.

MP 106. Sagavanirktok, 4 sheets. $\$ 52$.

MP 107. Selawik, 5 sheets. $\$ 65$.

MP 108. Shungnak, 5 sheets. \$65.

MP 109. Sleetmute, 4 sheets. $\$ 52$.

MP 110. Solomon, 5 sheets. $\$ 65$.

MP 111. Survey Pass, 5 sheets. $\$ 65$.

MP 112. Taku River, 4 sheets. \$52.

MP 113. Talkeetna, 5 sheets. $\$ 65$.

MP 114. Tanana, 5 sheets. $\$ 65$.

MP 115. Taylor Mountains, 4 sheets. \$52.

MP 116. Teshekpuk, 5 sheets. $\$ 65$.

MP 117. Tyonek, 5 sheets. $\$ 65$.

MP 118. Ugashik, 5 sheets. $\$ 65$.

MP 119. Umiat, 5 sheets. $\$ 65$.

MP 120. Unalakleet, 5 sheets. $\$ 65$.

MP 121. Utukok River. \$65.

MP 122. Wiseman, 5 sheets. $\$ 65$.

MP 129. Survey of geology, geologic materials, and geologic hazards in proposed access corridors in selected quadrangles, Alaska, by R.D. Reger, D.S.P. Stevens, G. R. Cruse, and H.R. Livingston, 2003, 72 p. \$7.

MP 132. Geologic hazards in and near the northern portion of the Bristol Bay Basin, by D.S.P. Stevens and P.A. Craw, 2003, 11 p. $\$ 2$.
MP 134. Geologic hazards on and near the northern coast of the Alaska Peninsula, by D.S.P. Stevens and P.A. Craw, 2004, 20 p. $\$ 2$.

\section{PRELIMINARY INTERPRETIVE REPORT}

PIR 2003-2. Principal facts for gravity data collected in the Copper River Basin area, southcentral Alaska, by J.F. Meyer Jr. and P.L Boggess, 2003, 12 p. \$2.

PIR 2003-3. Principal facts for gravity data collected in the Sustina Basin area, southcentral Alaska, by J.F. Meyer Jr. and P.L Boggess, 2003, 13 p. \$2.

PIR 2004-2. 2003 Megafossil report from the Chandler Lake Quadrangle, North Slope, Alaska, by W.P. Elder and Andrea Loveland (comp), 2004, 5 p. \$2.

PIR 2004-3. Geologic maps of the Livengood SW C-3 and SE C4 quadrangles, Tolovana mining district, Alaska, by J.E. Athey and P.A. Craw, 2004, 24 p. \$3.

PIR 2004-3a. Geologic map of the Livengood SW C-3 and SE C4 quadrangles, Tolovana mining district, Alaska, by J.E. Athey, M.B. Werdon, R.J. Newberry, D.J. Szumigala, P.A. Craw, and S.A. Hicks, 2004, 1 sheet, scale 1:50,000. \$13.

PIR 2004-3b. Bedrock geologic map of the Livengood SW C-3 and SE C-4 quadrangles, Tolovana mining district, Alaska, by J.E. Athey, D.J. Szumigala, R.J. Newberry, M.B. Werdon, and S.A. Hicks, 2004, 1 sheet, scale 1:50,000. \$13.

PIR 2004-5. Reservoir characterization pilot study: porosity and permeability of 148 Tertiary to Mississippian age outcrop samples, eastcentral Brooks Range Foothills, and North Slope, Alaska, by R.R. Reifenstuhl and A.L. Strauch, 2004. \$3.

\section{RAW DATA FILE}

RDF 2004-3. Summary of May 25-June 4, 2004, field notes and samples, Puale Bay and Wide Bay areas, Alaska Peninsula, by R.R. Reifenstuhl, D.C. Shafer, T.J. Ryherd, D.W. Brizzolara, and R.B. Blodgett, 2004, 16 p. \$3.

\section{REPORTS OF INVESTIGATIONS}

RI 2004-1b. Bedrock geologic map of the Salcha River-Pogo area, Big Delta M.B. Werdon, R.J. Newberry, J.E. Athey, and D.J. Szumigala, 2004, 19 p., 1 sheet, scale 1:63,360. \$15.

\section{ORDERING INFORMATION}

For each publication ordered, include both the publication title and number. Mail orders are payable in advance. Make check or money order in U.S. currency and payable to the State of Alaska. Credit cards are accepted. Telephone orders are accepted by the Fairbanks office between 8 a.m. and 5 p.m. Alaska time. Fax and email requests are accepted any time; these orders will be invoiced. If you would like to leave your order on voice mail, this can also be done 24 hours a day and you will be invoiced.

\section{SHIPPING \& HANDLING}

-Domestic postage - \$1.00/copy of each report

- Canada and Mexico - \$1.50/copy of each report

-All other international - $\$ 2.50$ surface

$\$ 5.00$ air/copy of each report

- For rolled-map orders requiring mailing tubes, include an additional $\$ 3.50$.

\section{WHERE TO ORDER}

Publications of the Division of Geological \& Geophysical Surveys are available over the counter, by mail, phone, fax, or email from the DGGS Fairbanks office:

ATTN: Geologic Communications Section-Publication Sales

Alaska Division of Geological \& Geophysical Surveys, 3354 College Rd.

Fairbanks, AK 99709-3703

(907) 451-5020 Fax (907) 451-5050

Email: dggspubs@dnr.state.ak.us

Prices of DGGS publications are subject to change. Increases in costs make it necessary to raise the selling prices of many publications offered. It is not feasible for DGGS to change the prices stated in previous announcements and publications in stock, so the prices charged may differ from the prices in the announcements and publications. Overpayments of $\$ 2$ or less will not be refunded. 


\section{STATE OF ALASKA \\ DEPARTMENT OF NATURAL RESOURCES \\ DIVISION OF GEOLOGICAL \& GEOPHYSICAL SURVEYS}

Mail order to:

Division of Geological \& Geophysical Surveys

Attn: Geologic Communications Section

Publication Sales

E-maildggspubs@dnr.state.ak.us

http://wwwdggs.dnr.state.ak.us

Phone: (907) 451-5020

3354 College Rd.

Fax: (907) 451-5050

Fairbanks, Alaska 99709-3707

\begin{tabular}{|c|c|c|c|c|c|}
\hline REPORT NO. & TitLe & QuANTITY & $\begin{array}{l}\text { UNIT } \\
\text { PRICE }\end{array}$ & Postage & TotaL \\
\hline & & & & & \\
\hline & & & & & \\
\hline & & & & & \\
\hline & & & & & \\
\hline & & & & & \\
\hline & & & & & \\
\hline & & & & & \\
\hline & & \multicolumn{3}{|c|}{ Total amount due } & \\
\hline
\end{tabular}

Domestic postage $\$ 1.00$ per copy of each report ordered Canada and Mexico, $\$ 1.50$ per copy of each report ordered

All other international, $\$ 2.50$ surface, $\$ 5.00$ air mail per copy of each report ordered

\section{Ship publication(s) to:}

Name

Organization

Address

City, State Zip

Payment must accompany your order. Make check or money order payable to STATE OF ALASKA.

We accept Visa and Mastercard. For payment by credit card, please contact our office at (907)451-5020. 

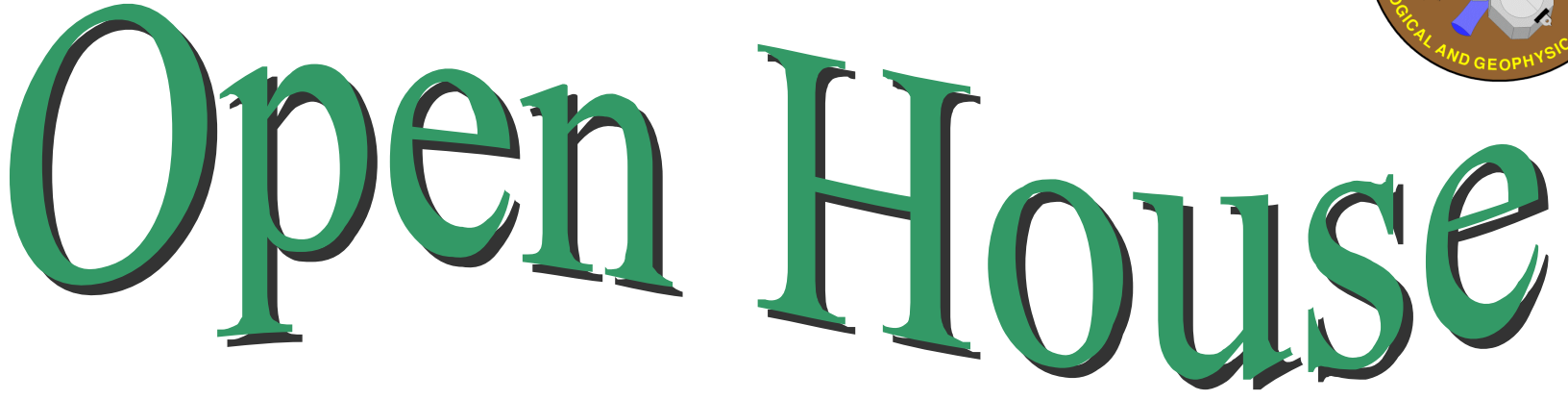

3354 College Rd. Fairbanks, Alaska

Tuesday, October 12, 2004-12:00-5:30pm

The Alaska Division of Geological er Ge ophysical $S$ urveys has settled into a new location. Ple ase join us for an open house

Tuesday, October 12, 2004. Staff will be available from 12-5:30 pm to give you a tour of our office.

Refreshments will be served!

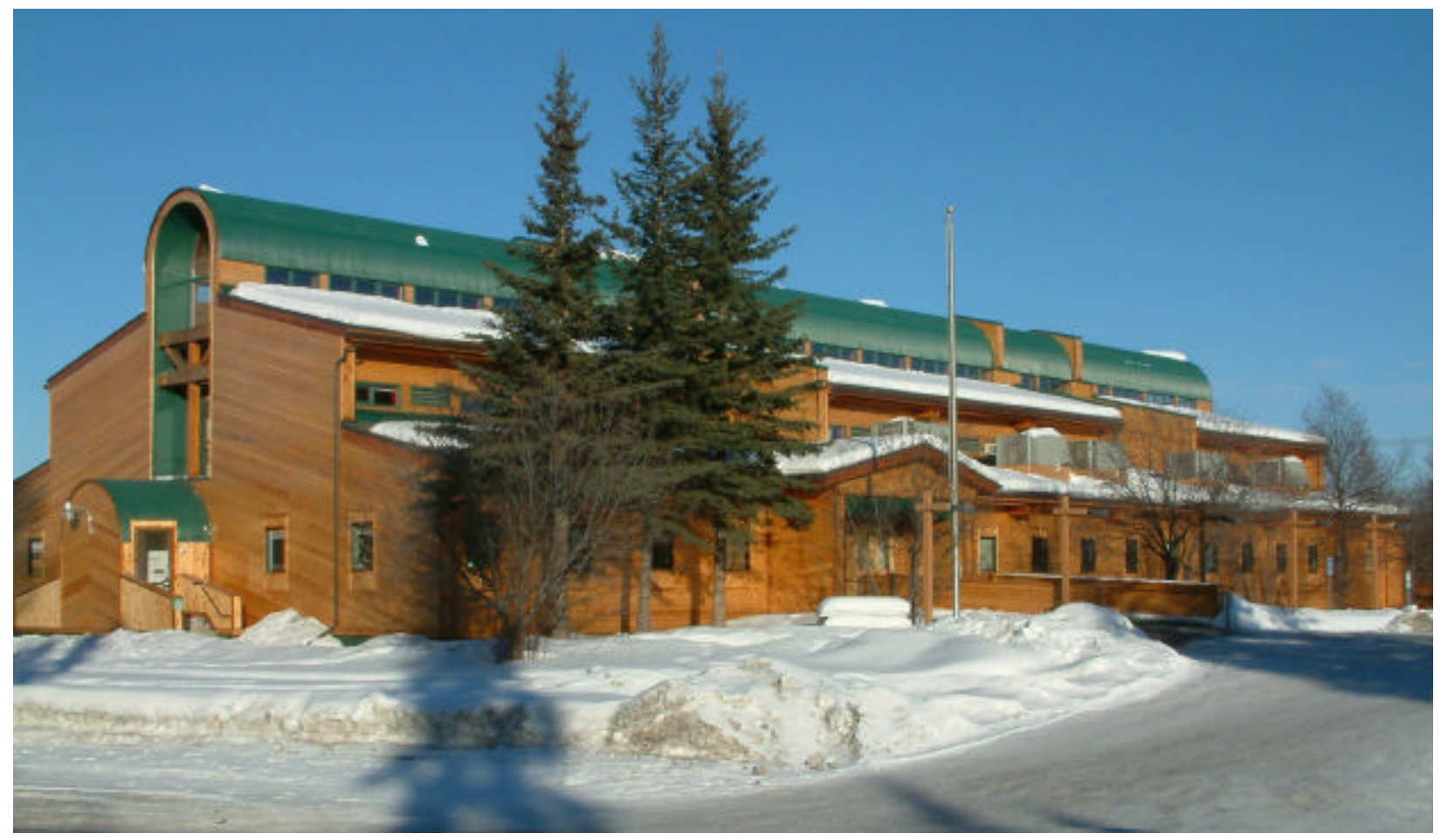

